\title{
Uyuşuk Çene Sendromu veya Malign Mental Nöropati; Klinik Bulgular ve Prognoz Derlemesi
}

\author{
Numb Chin Syndrome or Malign Mental Neuropathy; A Review of \\ Clinical Characteristics and Prognosis
}

\author{
Mehmet Emin Toprak, Orhan Kazan
}

Gazi Üniversitesi Diş Hekimliği Fakültesi Ağız Diş ve Çene Cerrahisi Anabilim Dalı, Ankara, Türkiye

\begin{abstract}
Özet: Uyuşuk çene sendromu veya malign mental nöropati kanser hastalığının; mental sinirin uç dalları ile innerve edilen alt dudak, çene ucu, ağız mukozası ve diğer bölgelerde uyuşukluk veya his kaybı ile karakterize bulgusudur. Uyuşuk çene sendromu agresif malign gidişatın bulgularındandır. Bu derlemede amaç; uyuşuk çene sendromunun etyolojik, patolojik, klinik özellikleri ve prognozunu değerlendirmektir. Mental nöropatinin en yaygın nedenleri iyi karakterize dental patolojiler ve iatrojenik maksillofasiyal komplikasyonlardır. Uyuşuk çene sendromuna en sık sebep olan maligniteler meme kanseri, lenfomalar, prostat kanseri ve lösemidir. Bu sendrom malign hücrelerin direkt infiltrasyonu, sinire basısı, sinir yolu ile yayılımı veya immün cevaplar sonucu oluşabilmektedir. Daha önceden geçirilmiş kanser öyküsü olan hastalarda bu sendrom tümörün nüksünün ve kötüye gidișin bir bulgusu olarak değerlendirilmektedir. Yapılan bu derlemede bu bulguları gösteren kanser hastalarında mortalite oranının $\% 80$ ve sağ kalım süresinin ortalama 7 ay olduğu bildirilmiştir. Bu sendrom bulguları olan hastalar panoramik filmlerden sonra, konik ışınlı bilgisayarlı tomografi, manyetik rezonans görüntülemeler ve pozitronemisyon görüntülemeler ile değerlendirilmelidir. Yapılan ek görüntüleme yöntemleri malign vakaların \%90'ında tanı konulmasını sağlamaktadır. Mental sinirin innerve ettiği bölgelerde uyuşukluğu olan hastaların dikkatli muayene edilmesi gerekmektedir. Uyuşuk çene bulguları sadece tanısı konulabilen sebeplerden dolayı değil aynı zamanda malignite varlığı açısından da dikkate alınmalıdır.
\end{abstract}

Anahtar Kelimeler: Uyuşuk çene sendromu, malignite, mental sinir, metastaz

\begin{abstract}
Numb chin syndrome or malign mental neuropthy is a neurological manifestation of cancer and its metastasis that appears by the sensorial neuropathy of the mental nerve characterized by paresthesia or hypoesthesia of the lover lip, chin, oral mucosa and other regions which are supplied by the mental nerve branches. Its appearance is associated with an ominous prognosis. The aim of this review on numb chin syndrome is to explain the etiology, the pathogeny, the clinical characteristics and prognosis. Benign dental pathologies and iatrogenic maxillofacial complications are the most common cause of mental neuropthy. The most common malignancies that cause numb chin syndrome are breast cancer, lymphomas, prostate cancer, and leukemia. Numb chin syndrome may occur by the direct infiltration, perineural invasion, nerve compression, leptomeningeal involvement, and immune mediated mechanisms of the malignancies. Numb chin syndrome in neoplasia patients may indicate recurrence of the tumor, and is associated with an ominous prognosis. In a review, the mortality rate of the cases which have the symptoms of this syndrome was found $80 \%$, with a mean survival of 7 months. Numb chin syndrome patients should be evaluated with investigations as orthopantogram, cone beam computed tomography, magnetic resonance imaging, bone scan, and positron-emission tomography-computed tomography. Additional investigations can be helpful in diagnosing the etiology in about $90 \%$ of malignant cases. The presence of mental nerve numbness symptoms requires careful examination of patients. Numb chin symptoms should be indicative not only for the bening factors but also for the presence of malignancy.
\end{abstract}

Keywords: Numb chin syndrome, malignant, mental nerve, metastasis

ORCID ID of the authors: M.E.T. 0000-0003-4281-5913, O.K. 0000-0001-8762-0533 


\section{Giriş}

Uyuşuk çene sendromu veya malign mental nöropati; mental veya alveoler sinirin uç dallarının etkilenmesi sonucu çene, alt dudak, oral mukoza gibi bölgelerde azalmış his kaybı ya da tamamen hissizlik olarak tanımlanan duyusal nöropatidir (1). Uyuşuk çene sendromunun mekanizmaları arasında direkt infiltrasyon, perinöral invazyon, sinir kompresyonu, leptomeningeal tutulum ve immün aracılık vardır (2).

\section{Amaç}

$\mathrm{Bu}$ derlemede amaç uyuşuk çene sendromunun etyolojik, patolojik, klinik özellikleri ve prognozunu değerlendirmektir.

\section{Bulgular ve Tartışma}

Malign mental nöropati için ayırıcı tanıda neoplastik hastalıklar, travmatik çene ve yüz yaralanmaları, diş kaynaklı enfeksiyonlar, toksik durumlar, ilaca bağlı etkileşimler, enflamatuvar süreçler, otoimmün veya enfeksiyöz nedenler dikkatli bir şekilde değerlendirilmelidir. Neoplastik hastalarda metastaz kötü prognoz ile ilişkilidir. Uyuşuk çene sendromunun ortaya çıkması durumunda bu hastalıkların incelenmesi ve takibinin yapılmas1 gerekmektedir (3). Neoplastik hastalarda oral ve maksillofasiyal bölgelerin metastazı genellikle nadirdir. Ancak bu bölge malignite tutulumları değerlendirildiğinde sirasiyla; meme kanseri $(\% 40,4)$; lenfoma $(\% 20,5)$, prostat kanseri $(\% 6,6)$, lösemi $(\% 5,1)$ şeklinde sıralanmaktadır (4).

İatrojenik yaralanmalar, sinirle ilişkili gömülü dişlerin veya kistlerin çıkarılması, rejyonel mandibular anestezi, kemik greftleme, endodontik tedavi, ortognatik cerrahi, dental implant, bifosfonat, meflokin, allopuinol, interferon alfa, trikloroetilen, sifiliz, lyme hastalığı, herpes, HIV, multiple skleroz, giant cell arterit, hepatit B, Sjögren sendromu ve romatoid artrit uyuşuk çene sendromunun ayırıc1 tanisinda göz önünde bulundurulmalıdır (5).

Çene bölgesinde malignitelerin en s1k metastaz gösterdiği yer mandibular molar bölgedir. Mandibular molar bölgede metastazın daha s1k görülme nedeni; kan akışının az olması, hematopoetik kemik iliği varlığı ve mental sinir laserasyonlarının sik olmasidir (6).

Uyuşuk çene sendromu olan hastalar ortopantogram (panoromik), bilgisayarlı tomografi, manyetik rezonans görüntüleme, kemik taraması ve pozitron emisyonlu bilgisayarlı tomografi (PET-CT) ile radyolojik açıdan incelenmelidirler (7).

Genellikle malignitenin kemiğe direkt infiltrasyonu ya da kemik invazyonu sonras1 görülen uyuşuk çene sendromu bazı vakalarda merkezi sinir sisteminin etkilenmesinden kaynaklı sekonder bir şekilde de ortaya çıkabilmektedir. $\mathrm{Bu}$ durumun gelişmesine Anti-Hu antikorunun neden olduğunu savunan hipotezler vardır fakat daha fazla çalışma yapılmasına ihtiyaç duyulmaktadır (8).

Standart tedavi yaklaşımlarına göre malignitesi olan hastalarda yaygin metastaz varsa genellikle ilk tedavi mevcut semptomları azaltmak için palyatif tedavilerdir. Bifosfanat türevi ilaçlar ya da sistemik endokrin tedavisi en s1k uygulanan tedavi alternatifleridir. Malign mental nöropati görülen vakalarda cerrahi rezeksiyon sadece soliter metastatik hastalarda düşünülmelidir (9).

Malign mental nöröpati görülen hastalarda, malignitenin nüks oranı çok yüksektir. Yapılan sistematik derlemelerde bildirilen vaka serilerine göre \%78,5'e yakın mortalite oran1 bildirilmektedir. $\mathrm{Bu}$ semptomun görüldüğü hastalarda ortalama sağ kalım beklentisi 6,9 ay olarak gösterilmiştir. Uyuşuk çene sendromu altta yatan ileri metastatik malignitelerin işareti olabileceği için hiçbir zaman göz ardı edilmemelidir (4). 


\section{Sonuç}

Mental sinirin innerve ettiği bölgelerde uyuşukluğu olan hastaların dikkatli muayene edilmesi gerekmektedir. Uyuşuk çene bulguları sadece tanisı konulabilen sebeplerden dolayı değil aynı zamanda malignite varlığ açısından da dikkate alınmalıdır.

\section{KAYNAKLAR}

1. Laurencet FM, Anchisi S, Tullen E, Dietrich P. Mental neuropathy: report of five cases and review of the literature. Critical reviews in oncology/hematology. 2000;34:71-9.

2. Alentorn A, Montero J, Vidaller A, Casasnovas C. Numb chin syndrome as an early symptom of primary and secondary vasculitis. Joint, bone, spine: revue du rhumatisme. 2011;78:427-8.

3. García-Álvarez SM, Olondo-Zulueta L, Pericás JM, Bosch X, Colomo L. Numb chin syndrome with vagal and hypoglossal paralysis: an initial sign of an uncommon diagnosis. The American journal of the medical sciences. 2012;344:241-4.

4. Galán SG, Peñarrocha MD. Malignant mental nerve neuropathy: systematic review. Medicina Oral, Patologia Oral y Cirugia Bucal. 2008;13:E616-21.

5. Maeda K, Taniguchi J-i, Matsui K. Two cases of numb chin syndrome diagnosed as malignant disease. Oxford Medical Case Reports. 2018;2018:omy097.

6. Fan Y, Luka R, Noronha A. Non-Hodgkin lymphoma presenting with numb chin syndrome. Case Reports. 2011;2011:bcr0120113712.

7. Hirshberg A, Shnaiderman-Shapiro A, Kaplan I, Berger R. Metastatic tumours to the oral cavitypathogenesis and analysis of 673 cases. Oral oncology. 2008;44:743-52.

8. Raaphorst J, Vanneste J. Numb cheek syndrome as the first manifestation of anti-Hu paraneoplastic neuronopathy. Journal of neurology. 2006;253:664.

9. Nambiar R, Anoop T, Haridas L, Daniel S. Numb Chin Syndrome as the Initial Manifestation of Breast Carcinoma. Indian journal of surgical oncology. 2018;9:391-3. 